\title{
PERENCANAAN DAN PENYUSUNAN MUATAN PADA KAPAL LANDING CRAFT TANK (LCT)
}

\section{Lis Lesmini}

ITL TRISAKTI

Email : lies.1969@yahoo.com

\section{Amalia Anggraini}

ITL TRISAKTI

Email : amalianggra@gmail.com

\section{Muhammad Rifni}

ITL TRISAKTI

Email : rifnim@gmail.com

\section{ARTICLE INFO}

Keywords:

Stowage Plan, Landing Craft Tank, Effectiveness
The purpose of this study was to determine the effect of load preparation planning on the effectiveness of load time, determine the effect of heavy load loading implementation on load time effectiveness and to determine the effect of load preparation planning and heavy load loading implementation on load time effectiveness. In this study found several problems that occur in the field including damage to mobile cranes, the occurrence of broken stowage and limitations of the dock which results in delays in the loading process. The population of this research respondents were 115 employees tested using Slovin theory, the minimum results obtained were 53 respondents and were sampled in this study. Validity test obtained by $\mathrm{r}$ table $(\mathrm{n}-2)=53$ respondents with a $5 \%$ error level that is equal to 0.270 . Based on the test, it is said that all the items in each research variable are valid. The results of the Cronbach's Alpha reliability test of the three variables used in this study is greater than 0.60 , it is concluded that the statements of each of these research variables are real. To test the variables as a whole where the variables $\mathrm{X} 1$ and $\mathrm{X} 2$ have an effect on Y variables simultaneously, the results of Fcount analysis are 28.664 and for Ftable values are 3.18. The value of Fcount> Ftable proves that Ho is rejected and $\mathrm{Ha}$ is accepted. Based on the analysis by linear regression, that the multiple correlation obtained by $\mathrm{R}$ for 0.731 or $73.1 \%$ means that the influence of X1 and X2 together on $\mathrm{Y}$ is positive and significant from the simultaneous test (F test) and the results of multiple correlation analysis, it can be concluded that variable $\mathrm{X} 1$ against $\mathrm{Y}$ with Correlation coefficient is 0.305 or $30.5 \%$ and $\mathrm{X} 2$ against $\mathrm{Y}$ with a correlation coefficient of 0.681 or $68.1 \%$. 



\section{PENDAhULUAN}

PT. Aditya Aryaprawira Shipping sebuah perusahaan yang melayani segala pengangkutan muatan berat sebagai kebutuhan industry baik pengangkutan skala nasional maupun internasional. Bidang usaha perusahaan ini adalah: melayani kegiatan sewa menyewa kapal (Ship Chartering), kegiatan pengangkutan alat berat (Project Movement), industry, pertambangan dan muatan berbahaya, kegiatan keagenan kapal, pengurusan dokumen dan custom clearance, stevedoring dan pergudangan, kegiatan keperluan lepas pantai, kegiatan trucking, receiving dan delivery. Dalam operasinya perusahaan ini mengoperasikan 12 unit armada kapal, diantaranya 4 kapal LCT (Landing Craft Tank) dengan bobot mati 2000 ton, 3 kapal Tug boat, 3 kapal tongkang dengan total bobot mati 5500 ton, dan 2 kapal Hopper Barge dengan bobot mati 800 ton.

Dalam proses pemuatan muatan terutama muatan berat ditemukan beberapa masalah terkait dengan operasional kapal di antara lain adalah keterbatasan mobile crane, karena PT. Aditya Aryaprawira hanya menggunakan Mobile Crane, sehingga bila terjadi kerusakan pada Mobile Crane maka kegiatan bongkar muat tidak dapat dilakukan sesuai waktu yang ditetapkan, akibatnya akan terjadi penundaan waktu bongkar muat karena harus menunggu penggantian crane cadangan. Selain keterbatasan mobile crane juga faktor keterbatasan dermaga yang juga dapat menyebabkan terjadinya penundaan kapal dari saat menunggu menuju tempat sandar, maka waktu pelayanan kapal menjadi lebih lama. Keterbatasan alat dalam kegiatan bongkar muat serta dermaga tersebut dapat mempengaruhi Berthing Time (waktu kapal di dermaga) dan Berth Working Time (waktu kerja kapal di dermaga) sehingga berpengaruh pada waktu kegiatan bongkar muat. Pelaksanaan bongkar muat alat berat juga dapat mempengaruhi waktu TRT dari kapal yang di layani di suatu pelabuhan. Turn Round Time (TRT) adalah waktu kedatangan Kapal berlabuh jangkar di Dermaga serta waktu keberangkatan Kapal setelah melakukan kegiatan bongkar muat barang, semakin lama kegiatan bongkar muat di pelabuhan maka semakin besar dampak kepada biaya pelabuhan yang dikenal sebagai demurage. Demurage adalah biaya yang dikenakan kepada kapal apabila terlambat dari waktu yang ditentukan untuk berlabuh disuatu pelabuhan. Selain itu muatan kapal LCT (Landing Craft Tank) yang berbeda jenis, berat, Panjang serta lebar yang menyebabkan daya tampung kapal tersebut menjadi berkurang sehingga dapat mengakibatkan terjadinya broken stowage, dimana yang seharusnya kapal mampu menampung lebih banyak muatan menjadi terbatas karena ruang-ruang yang tidak terpakai tersebut. Broken stowage adalah besarnya persentase (\%) jumlah ruangan yang hilang atau ruang yang tidak terpakai ruang rugi pada pengaturan muatan dalam suatu palka. Persentase kehilang ruang rugi (Broken stowage) suatu palka dapa dihitung dengan rumus. Adapun penyebab utama broken stowage adalah: Space yang ditnggalkan untuk 

memisahkan consignment cargo, Space yang telah hilang karena muatan yang bentuknya tidak teratur sehingga tidak dapat dipadatkan dalam penumpukan, Space yang ditempati oleh dunnage dan bahanbahan lain yang digunakan dalam stacking, Space yang ditempati oleh palet-palet dimana muatan di stack. Untuk mengatasi terjadinya Broken stowage maka hal-hal yang harus dilakukan adalah: Pemilihan bentuk muatan yang sesuai dengan bentuk palka, Pengelompokan dan pemilihan jenis muatan, Penggunaan muatan pengisi, Pengawasan pengaturan muatan, Penggunaan Dunnage seminim mungkin (Mudiyanto, 2018)

Penanganan muatan harus memenuhi lima prinsip pemuatan yang baik diantaranya melindungi awak kapal dan buruh, melindungi kapal, melindungi muatan, melakukan muat bongkar secara tepat dan sisematis serta penggunaan ruang muat semaksimal mungkin (Kosasih, 2000). Untuk itu diperlukan perencanaan pemuatan (Stowage Plan) yang baik agar dapat memenuhi prinsip efisien dan efektif dalam penyusunan muatan ke dalam ruang kapal sehingga pemuatan dapat berjalan lencar dan memenuhi efektivitas waktu muat.

\section{KAJIAN PUSTAKA}

Kapal adalah kendaraan air dengan bentuk dan jenis tertentu, yang digerakkan dengan tenaga angin, tenaga mekanik, energi lainnya, ditarik atau ditunda, termasuk kendaraan yang berdaya dukung dinamis, kendaraan di bawah permukaan air, serta alat apung dan bangunan terapung yang tidak berpindah-pindah (Kemenhub, 2016). Kapal yang mengawali perjalanannya dengan berlayar dilaut dari pelabuhan asal dan pelabuhan tujuan yaitu merupakan sebuah aktivitas kapal dalam mengirim muatan. pada saat kapal melakukan kegiatan labuh dan tambat dipelabuhan tertentu maka kapal tersebut sedang dalam proses mengambil muatan untuk diangkut ke tempat tujuan dan mengirimkan muatan tersebut kepada pihak pemilik barang

Kapal Landing Craft Tank (LCT) adalah salah satu jenis kapal yang digunakan dalam transportasi laut komersil sebab kapal ini benar-benar efisien dalam pengangkutan bulldozer, heavy cargo, dump truck, excavator, loader, serta berbagai alat berat yang lainnya dimana alat-alat berat tersebut benarbenar dibutuhkan dalam menjalankan pekerjaan atau proyek konstruksi dan pekerjaan pertambangan dan juga dapat mengangkut bahan-bahan konstruksi yang notabenenya berukuran besar, contohnya seperti lembaran baja, pipa besi, tanki air, dan lain-lain, yang pasti di proyek pembangunan itu dibutuhkan. Kelebihan lainnya adalah kapal ini dapat mengangkut muatan ke berbagai penjuru Indonesia, terutama ke daerah pertambangan yang berada dipulau atau pantai terpencil. Kapal Landing Craft Tank (LCT) tidak memerlukan dermaga khusus untuk sandar dalam melakukan proses bongkar 

muat dikarenakan kapal tersebut memiliki rampdoor dan draft kapal yang rendah dikarenakan jalur pelayaran yang akan ditempuh untuk mencapai daerah terpencil biasanya melewati sungai, pantai dan sejenisnya.

Menurut (Zumar, 2018) Landing Craft Tank adalah sebuah kapal pendarat serang untuk mendaratkan tank di tepi pantai. Kapal ini mulai muncul pada saat Perang Dunia II dan digunakan oleh Angkatan Laut Inggris dan Amerika Serikat Kapal jenis Landing Craft memiliki dek yang luas dan rata sehingga cocok untuk mengangkut kendaraan maupun bahan logistik ke daerah- daerah pertambangan; terutama yang terletak di pulau atau daerah terpencil.

Gambar 1. Kapal LCT

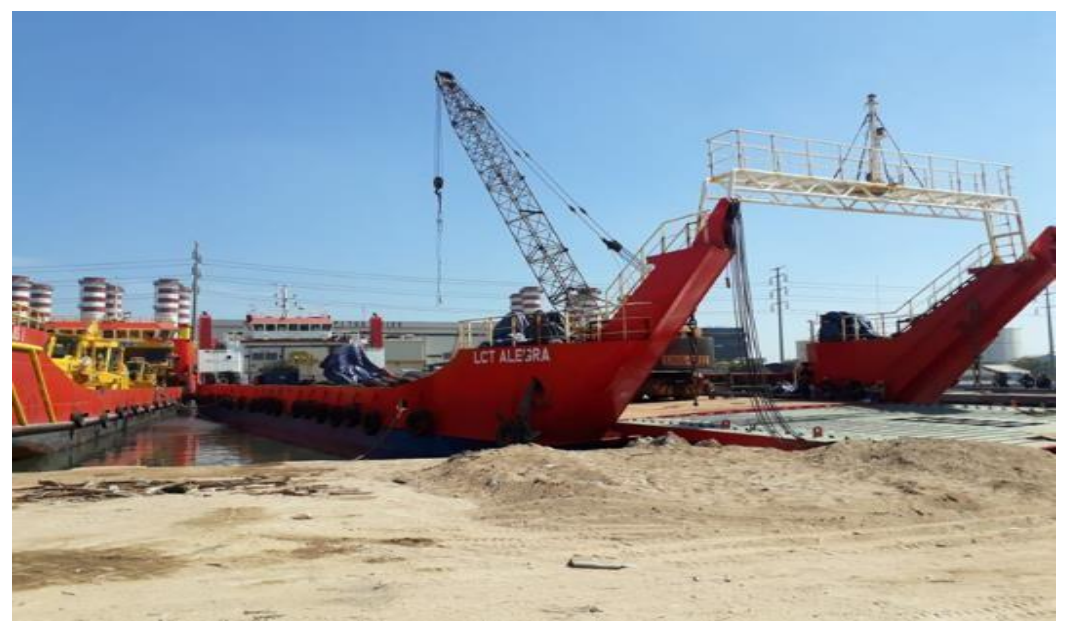

Sumber : PT. Aditya Aryaprawira Tahun 2017

Gambar 2. Penyusunan Muatan pada Kapal LCT Allegra (2017)

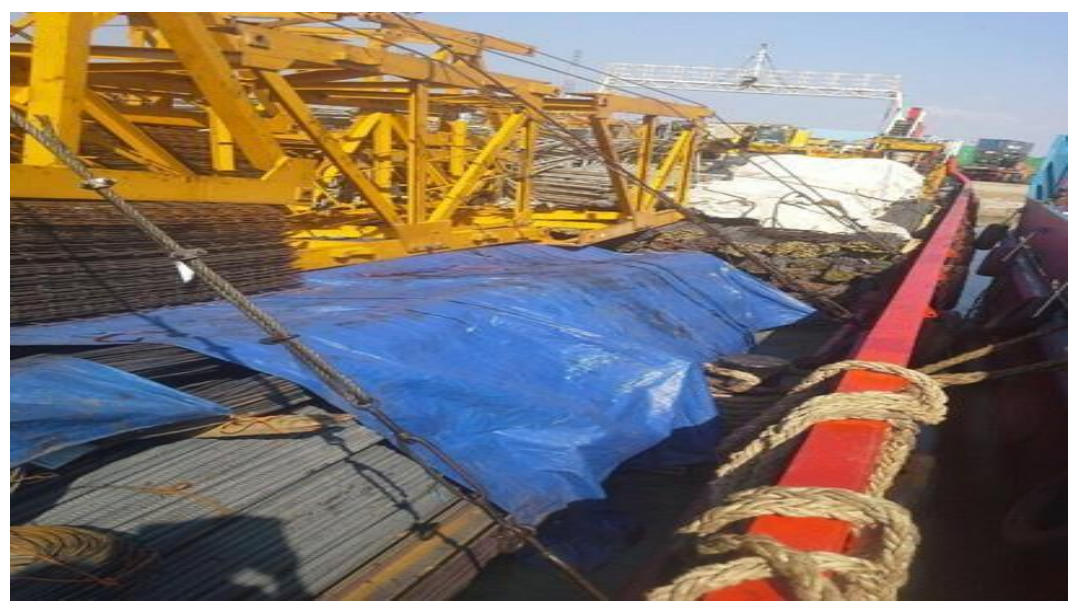

Sumber : PT. Aditya Aryaprawira Tahun 2017 
Dalam proses bongkar muat serta penyusunan muatan kedalam alat transportasi laut, khususnya untuk muatan berat dibutuhkan penanganan yang baik dan sistematis agar proses penyusunan dapat berlangsung secara efektif dan efisien Perencanaan pemuatan (stowage plan) adalah perencanaan penataan dan penempatan muatan yang akan di muat pada palka-palka kapal mengenai jumlah, berat dan letak. Kegiatan ini harus mempertimbangkan muatan pada pelabuhan sebelumnya, pelabuhan tujuan, kekuatan dan stabilitas kapal. Stowage Plan atau pemadatan muatan adalah penempaatan dan penyusunan muatan disesuaikan dengan sifat, bentuk, jenis bungkusan dan tujuan muatan masingmasing. Sehubungan dengan hal tersebut, penempatan dan penyusunan muatan (Stowage), harus dilakukan dengan benar dan dijaga stabilitas kapal serta keselamatan pelayaran juga perlu dijaga.

Masalah pengoperasian armada kapal kontainer yang melayani banyak pelabuhan secara efisien terdiri dari beberapa sub-masalah, di antaranya menemukan ukuran optimal dan rute optimal kapal. Selain itu, pemindahan kontainer ke dan dari kapal harus dilakukan dengan cepat dan efisien. Dengan kapal yang sangat besar saat ini, yang membutuhkan ribuan gerakan kontainer untuk memuat dan melepaskan, sangat sulit untuk mencapai efisiensi tersebut. Selain itu, untuk operasi pengiriman yang hemat biaya, sangat penting untuk mengoptimalkan pemanfaatan kapal itu sendiri. Efisiensi pelabuhan dan pemanfaatan kapal sangat ditentukan oleh penyimpanan kapal, pengaturan kontainer di atas kapal. Tugas menentukan pengaturan wadah terbaik disebut Stowage Plan (Avriel, Mordecai, Michael Penn, 1998)

Menurut Martopo (2004) Penataan muatan atau Stowage yaitu suatu pengetahuan tentang memuat dan membongkar muatan dari dan ke atas kapal tentang jenis-jenis muatan, perencanaan pemuatan, sifat serta kualitas barang yang akan dimuat, perawatan muatan, penggunaan alat-alat pemuatan, dan ketentuan-ketentuan yang lain yang menyangkut masalah keselamatan kapal dan muatan. Sedangkan (Martopo, 1999) menyatakan bahwa "Stowage Plan adalah sebuah rencana pemuatan yang dibuat atau direncanakan sebelum pemuatan barang, bagi seluruh muatan yang ada dikapal". Berdasarkan beberapa pendapat ahli di atas dapat disimpulkan bahwa Perencanaan Stowage Plan merupakan sebuah rencana pengaturan muatan dimana kita dapat mengetahui letak, jumlah dan berat muatan tersebut sehingga kegiatan bongkar muat dapat dilakukan dengan baik dan dapat memperhitungkan lamanya waktu bongkat muat berlangsung.

Jenis Stowage plan ada 2 (dua) macam yaitu : Tentative Stowage Plan adalah berupa gambaran ancar-ancar untuk suatu rencana pengaturan muatan yang dibuat sebelum kapal tiba di pelabuhan muat atau sebelum pelaksanaan pemuatan, dibuat dengan berdasarkan Booking List atau Shipping order yang diterima untuk suatu pelabuhan 
tertentu dan Final Stowage Plan yaitu gambaran informasi yang menunjukkan keadaan sebenamya dari letak-letak muatan beserta jumlah dan beratnya pada tiap-tiap palka yang dilengkapi dengan Consignment mark untuk masing-masing pelabuhan tertentu Setelah selesai mengadakan kegiatan Pengaturan muatan, maka kondisi muatan yang sebenamya yang terdapat didalam palka dapat dilihat dalam Stowage Plan ini, oleh karena itu, maka Stowage Plan seyogiyanya dibuat seteliti mungkin sebab termasuk salah satu dokumen yang cukup penting dan dapat berfungsi sebagai. bahan bukti pertanggung jawaban atas Pengaturan muatan didalam. palka bila terjadi tuntutan ganti rugi (claim) dari ;pemilik muatan (Consignee). Selain Stowage Plan yang dibuat oleh pihak Carrier sebagai bahan informasi mengenai muatan yang berada didalam masing-masing palka, maka pihak Carrier masih perlu membuat Hatch List dan Discharging List untuk melengkapi informasi yang tertera pada Stowage Plan, sebab sudah barang tentu informasi yang lengkap mengenai muatan tersebut, tidak dapat sepenuhnya tercakup dalam Stowage Plan. Adapun kegunaan dari pada Stowage Plan adalah dapat mengetahui letak tiap muatan serta jumlah dan beratnya, dapat merencanakan kegiatan pembongkaran yang akan dilakukan, dapat mememperhitungkan jumlah buruh yang diperlukan, dapat memperhitungkan lamanya waktu pembongkaran berlangsung dan sebagai dokumen pertanggung jawaban atas pengaturan muatan. Adapun kegunaan dari pada Stowage Plan adalah :dapat mengetahui letak tiap muatan serta jumlah dan beratnya, dapat merencanakan kegiatan pembongkaran yang akan dilakukan, dapat mememperhitungkan jumlah buruh yang diperlukan, dapat memperhitungkan lamanya waktu pembongkaran berlangsung dan sebagai dokumen pertanggung jawaban atas pengaturan muatan.

Prasetyo \& \& Benny, Agus (2011) menyatakan bahwa dalam sebuah pelaksanaan peningkatan produktivitas hasil kerja kegiatan bongkar muat barang tidak lepas dari adanya beberapa faktor yaitu sebagai berikut : Sumber Daya Manusia (SDM), Peralatan yang dibutuhkan yang terdiri atas: Mekanik seperti mobile crane, container crane, forklift, reach stacker, top loader dan Non mekanik yang merupakan alat pokok penunjang pekerjaan b/m yang meliputi jala-jala lambung kapal (shipside net), tali baja (wire sling), tali rami manila (rope sling), jala-jala baja (wire net), jala-jala tali manila (rope net), gerobak dorong, palet. Untuk memperlancar kegiatan bongkar muat barang tersebut dan mempersingkat waktu maka semua yang diperlukan baik Sumber Daya Manusia (SDM) maupun peralatan mekanis ataupun non mekanis harus disiapkan satu jam sebelum kegiatan bongkar muat barang berlangsung. Indikator dalam melakukan persiapan bongkar yaitu: Sumber Daya Manusia (SDM), Peralatan yang dibutuhkan terdiri atas :Mekanik seperti mobile crane, container crane, forklift, reach stacker, top loader,dll dan Non mekanik yang merupakan alat pokok penunjang pekerjaan 
bongkar muat yang meliputi jala-jala lambung kapal (shipside net), tali baja (wire sling), tali rami manila (rope sling), jala-jala baja (wire net), jala-jala tali manila (rope net), gerobak dorong palet. Untuk memperlancar kegiatan bongkar muat barang maka semua yang diperlukan baik Sumber Daya Manusia (SDM) maupun peralatan mekanis ataupun non mekanis harus disiapkan satu jam sebelum kegiatan bongkar muat barang berlangsung.lebih lanjut dijelaskan bahwa dalam sebuah pelaksanaan peningkatan produktivitas hasil kerja kegiatan bongkar muat barang tidak lepas dari adanya beberapa faktor yaitu sebagai berikut : Komoditi yang dibongkar, Jenis kemasan ada yang berupa bag, peti, bal, cair, petikemas sehingga membutuhkan penanganan yang berbeda-beda dan alat yang berbeda pula agar barang tidak rusak, Alat bongkar muat, Alat angkutan dan Keadaan cuaca

Efektivitas adalah suatu ukuran tentang bagaimana suatu target atau sasaran yang telah ditentukan tercapai yang mengacu pada hasil akhir. Hasil akhir adalah tujuan utama. Semakin mencapai taget yang ditentukan maka efektivitasnya semakin baik. Adapun- indikator dalam Efektivitas Waktu Muat adalah :Kualitas kerja, yaitu volume kerja yang dihasilkan dalam kondisi normal, Kuantitas kerja, dapat berupa kerapian ketelitian dan keterkaitan hasil dengan tidak mengabaikan volume pekerjaan, Pemanfaatan waktu, yaitu penggunaan masa kerja yang disesuaikan dengan kebijaksanaan perusahaan atau lembaga pemerintahan.

Menurut Setiono, (2013) Kata efektif berasal dari Bahasa inggris yaitu effective yang berarti berhasil atau sesuatu yang dilakukan berhasil dengan baik. Kamus ilmiah populer mendefinisikan efektifitas sebagai ketepatan penggunaan, hasil guna menunjang tujuan. Efektifitas merupakan unsur pokok untuk mencapai tujuan atau sasaran yang telah ditentukan di dalam setiap organisasi, kegiatan atau program. Disebut efektif apabila tercapai tujuan atau pun sasaran seperti yang telah ditentukan.

Efektivitas menggambarkan seluruh siklus input, proses dan output yang mengacu pada hasil guna daripada suatu organisasi, program atau kegiatan yang menyatakan sejauhmana tujuan (kualitas, kuantitas, dan waktu) telah dicapai, serta ukuran berhasil tidaknya suatu organisasi mencapai tujuannya dan mencapai target-targetnya., (Mahmudi, 2005). Berikut adalah indikator dari efektivitas yaitu : Kualitas kerja, yaitu volume kerja yang dihasilkan dalam kondisi normal, Kuantitas kerja, dapat berupa kerapian ketelitian dan keterkaitan hasil dengan tidak mengabaikan volume pekerjaan, Pemanfaatan waktu, yaitu penggunaan masa kerja yang disesuaikan dengan kebijaksanaan perusahaan atau lembaga pemerintahan. 


\section{METODE PENELITIAN}

Penelitian ini berlokasi pada Kapal Landing Craft Tank (LCT) Alegra di PT. Aditya Aryaprawira pada Tahun 2017. Yang menjadi populasi penelitian adalah seluruh karyawan yang berjumlah 115 orang. sedangkan sampel ditetapkan menggunakan teknik probability sampling dan bentuk yang digunakan adalah simple random sampling yang terdiri dari elemen, yang dipilih dari suatu populasi dengan cara sedemikian rupa atau acak. Dari data karyawan tahun 2017 seluruhnya berjumlah 115 karyawan berdasarkan uji slovin mendapatkan hasil minimum data yang dapat diolah adalah 53 responden. Jenis data yaitu data kualitatif dan data kuantitatif. Sumber Data menggunakan Data Primer dan data sekunder. Teknik pengumpulan data menggunakan Daftar Pertanyaan (Kuesioner) dan Wawancara (Interview) dan Observasi (Observation) serta Penelitian Kepustakaan (Library Research). Teknik Analisis Data menggunakan Analisis Regresi Linier Berganda yaitu Pengujian Secara Parsial (Uji-t), uji secara Simultan (Uji-F) Koefisien Determinasi dan Analisis Korelasi Berganda.

\section{HASIL DAN PEMBAHASAN}

Ada berbagai penelitian terdahulu yang dilakukan mengenai bongkar muat muatan pada kapal. Setiono, (2013) meneliti tentang Efektifitas Bongkar Muat Petikemas Terhadap Kelancaran Arus Barang di PT. Nilam Port Terminal Indonesia (NPTI) maka peneliti menyimpulkan sebagai berikut. Faktor-faktor yang mempengaruhi Bongkar Muat Petikemas di PT. Nilam Port Terminal Indonesia sebagai berikut. - Alat Bongkar Muat. - Kinerja TKBM. - Jalan. Faktor-faktor yang mempengaruhi Kelancaran Arus Barang di PT. Nilam Port Terminal Indonesia sebagai berikut. - Transportasi Darat (head truck). - Kinerja TKBM. - Sumber Daya Manusia (SDM).

Sedangkan (Mirade, Architania, Rifani., Rinitami, Njatrijani., \& Hendro, 206AD) melakukan penelitian dengan fokus mengenai aturan izin khusus yang wajib dimiliki. Adapun hasil penelitian menyimpulkan bahwa pelaksanaan kegiatan bongkar muat sedikit terhambat karena adanya aturan mengenai izin khusus yang wajib dimiliki oleh setiap Perusahaan Bongkar Muat. Tidak dimungkinkan PT. Pelindo III mengubah akta pendirian perusahaan menjadi khusus melakukan kegiatan bongkar muat sehingga perlu dibuatnya Kantor cabang Perusahaan Bongkar Muat di Pelabuhan dalam provinsi setempat.

Sementara itu (Agung, Pratama, 2014) dalam penelitiannya menemukan bahwa Pelaksanaan persiapan di kapal sangat mempengaruhi dalam kelancaran pemuatan batu bara dengan menggunakan floating crane, Langkah-langkah untuk mengoptimalkan penataan muatan batu bara di kapal MV. 
Andhika sharmila dengan menggunakan floating crane meliputi persiapan sebelum pemuatan, melakukan draft survey serta membuat kesepakatan antara floating crane dan kapal tentang stowage plan yang sudah dibuat oleh mualim I, membuka palka-palka dan siap untuk dimuati sesuai dengan stowage plan, setelah itu melaksanakan deballasting, melakukan trimming, dan pengawasan yang baik terhadap proses pemuatan.

Sedangkan (Nutfah, Indah, 2007) meneliti tentang Analisa Kinerja dan Efektivitas Bongkar Muat PadaTerminal Petikemas (TPK) Koja Dalam melakukan analisa kinerja bongkar muat, harus dilakukan perhitungan terhadap waktu bongkar muat, kecepatan bongkar muat kapal, produktifitas bongkar muat, serta utilisasi fasilitas bongkar muat.

Masalah pengoperasian armada kapal kontainer secara efisien melayani banyak pelabuhan terdiri dari beberapa sub-masalah, di antaranya menemukan ukuran optimal dan rute optimal kapal. Selain itu, pemindahan kontainer ke dan dari kapal harus dilakukan dengan cepat dan efisien. Dengan kapalkapal yang sangat besar saat ini, membutuhkan ribuan gerakan kontainer untuk memuat dan mengosongkan, cukup sulit untuk mencapai efisiensi tersebut. Lebih jauh lagi, untuk operasi pelayaran yang hemat biaya, sangat penting untuk mengoptimalkan pemanfaatan kapal itu sendiri. Efisiensi pelabuhan dan pemanfaatan kapal sangat ditentukan oleh penyimpanan kapal, pengaturan kontainer di atas kapal. Tugas menentukan pengaturan kontainer terbaik disebut Stowage Plan (Avriel, Mordecai, Michael Penn, 1998).

Perencanaan operasi di industri transportasi laut dapat sebagian besar dibagi menjadi tiga kategori, berdasarkan lamanya waktu perencanaan dilakukan: Perencanaan strategis, taktis, dan operasional. Perencanaan strategis berkaitan dengan horizon waktu beberapa tahun, dan biasanya melibatkan keputusan seperti menentukan ukuran dan campuran armada. Perencanaan taktis biasanya memiliki waktu dalam urutan bulan, dan masalah khasnya adalah menentukan kapal mana yang harus melayani rute mana. Perencanaan operasional berkaitan dengan keputusan jangka pendek, seringkali terkait dengan pelayaran yang diberikan, seperti pemilihan kecepatan, rute cuaca, atau penyimpanan. Saat melakukan perencanaan jangka panjang, kapal barang meletakkan rencana strategis untuk berapa banyak dan kapal mana yang harus dimiliki dan dioperasikan. Rencana strategis ini digunakan sebagai masukan untuk perencanaan taktis, seperti penempatan armada. Ketika kapal barang telah memutuskan kapal mana yang harus berlayar rute mana, ini digunakan sebagai input dalam perencanaan operasional. Dalam hal perencanaan penyimpanan, perencana biasanya telah diberikan kapal khusus untuk interval waktu tertentu, di mana kapal harus mengangkut kargo khusus atau berlayar dengan rute tertentu. Contoh rute dalam pengiriman RoRo diberikan pada Gambar. 1. Saat membuat rencana 
ini, perencana harus menyeimbangkan sama sekali ruang lingkup rencana dan keterlacakan masalah. Peningkatan cakupan, yaitu perencanaan untuk periode waktu yang lebih lama dan lebih banyak kapal secara bersamaan, memberi perencana lebih banyak fleksibilitas. Hal ini memungkinkan dia untuk menemukan solusi yang mengeksploitasi sinergi lebih baik daripada jika masalah dipartisi menjadi masalah yang lebih kecil dan diselesaikan secara berurutan. Namun, menyelesaikan masalah perencanaan dengan cakupan besar lebih sulit daripada menyelesaikan sub-masalah yang ada(Øvstebø, Hvattum, \& Fagerholt, 2011).

\subsection{Penyajian Data dengan Statistik Deskriptif}

Variabel di dalam penelitian adalah sbb :variabel perencanaan penyusunan muatan(X1) dan variabel pelaksanaan pemuatan muatan berat (X2) terhadap efektivitas waktu muat (Y). Adapun indikator tiap variable seperti terdapat pada tabel berikut ini :

Tabel 1 Kisi - kisi Instrumen

\begin{tabular}{|c|c|c|c|c|}
\hline $\begin{array}{l}\text { Operasional } \\
\text { Variabel }\end{array}$ & Dimensi V ariabel & Ind ikator & Skala & $\begin{array}{c}\text { No } \\
\text { kuesioner }\end{array}$ \\
\hline \multirow[t]{4}{*}{$\begin{array}{l}\text { Perenc anaan } \\
\text { Penyusunan } \\
\text { muatan }\left(\mathbf{X}_{1}\right)\end{array}$} & $\begin{array}{l}\text { a. Sumber Daya } \\
\text { Manusia (SDM) }\end{array}$ & $\begin{array}{l}\text { - Stowage plan } \\
\text { memudahkan proses } \\
\text { bongkar muat } \\
\text { Dapat menyelesaikan } \\
\text { tugas yang menjadi } \\
\text { tanggung jawab terhadap } \\
\text { - Pengawasan secara terus } \\
\text { proses muat secaras } \\
\text { menerus }\end{array}$ & $\begin{array}{l}\text { Interval } \\
\text { Interval } \\
\text { Interval }\end{array}$ & $\begin{array}{l}1 \\
2 \\
3\end{array}$ \\
\hline & 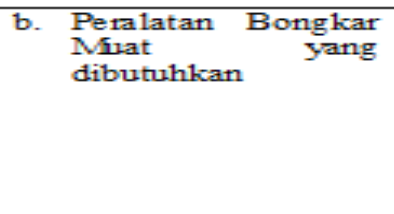 & $\begin{array}{l}\text { - Alat mekanis dalam kondisi } \\
\text { baik } \\
\text { - Alat non mekanis dalam } \\
\text { kondisi baik } \\
\text { - Ketersediaan alat bongkar } \\
\text { - Kuat sudah memadai } \\
\text { - Kesiapan alat ke seluruhan }\end{array}$ & $\begin{array}{l}\text { Interval } \\
\text { Interval } \\
\text { Interval } \\
\text { Interval }\end{array}$ & $\begin{array}{l}4 \\
5 \\
6 \\
7\end{array}$ \\
\hline & $\begin{array}{l}\text { a. } \begin{array}{l}\text { Komoditi } \\
\text { dibongkar }\end{array} \text { yang }\end{array}$ & $\begin{array}{l}\text { Penanganan muatan yang } \\
\text { berbeda jenis dan ukuran } \\
\text { dilakukan dengan baik }\end{array}$ & Interval & 1 \\
\hline & b. Jenis Kemasan & $\begin{array}{l}\text { Penanganan } \quad \text { terhadap } \\
\text { muatan yang berbeda sesuai } \\
\text { prosedur }\end{array}$ & Interval & 2 \\
\hline \multirow{4}{*}{$\begin{array}{c}\text { Pelaksanaan } \\
\text { Pemuatan } \\
\text { muatan berat } \\
\left(\mathbf{X}_{2}\right)\end{array}$} & c. A1 at Bongkar muat & $\begin{array}{l}\text { Mobile crane dapat } \\
\text { berfungsi dengan baik }\end{array}$ & & 3 \\
\hline & $\begin{array}{l}\text { Aroduktivitas } \\
\text { Tenaga Kerja } \\
\text { Bongkar } \\
\text { Minat(IKBMD }\end{array}$ & $\begin{array}{l}\text { - Tenaga Kerja Bongkar } \\
\text { Minat CIKBLD mampu } \\
\text { menangani proses muat } \\
\text { dengan baik } \\
\text { Crew kapa } 1 \text { mampu } \\
\text { menangani proses muat } \\
\text { dengan baik }\end{array}$ & $\begin{array}{l}\text { Interval } \\
\text { Interval }\end{array}$ & 4 \\
\hline & e. A1at Angkutan & $\begin{array}{l}\text { A.lat Angkut muatan sudah } \\
\text { memadai saat pelaksanaan } \\
\text { muat }\end{array}$ & Interval & 6 \\
\hline & f. Keadaan Cuaca & $\begin{array}{l}\text { Faktor cuaca buruk dapat } \\
\text { menghambat proses muat }\end{array}$ & Interval & 7 \\
\hline $\begin{array}{l}\text { Efelktivitas } \\
\text { W aktu Muat } \\
(Y)\end{array}$ & a. Kualitas Kerja & $\begin{array}{l}\text { - Kualitas kerja Tenaga Kerja } \\
\text { Bonglkar Mluat CIKBMD } \\
\text { sudah baik } \\
\text { PT. Aditya Aryaprawira }\end{array}$ & Interval & 1 \\
\hline
\end{tabular}




\subsubsection{Hasil Uji Validitas}

Berikut ini hasil perhitungan menggunakan program SPSS versi 20, terhadap item pertanyaan yang hasilnya seperti pada tabel di bawah ini.

a. Uji Validitas Variabel Perencanaan Penyusunan Muatan(X1)

Tabel 2 Uji Validitas Variabel Perencanaan Penyusunan Muatan (X1)

\begin{tabular}{|c|c|c|c|c|}
\hline No & Pernyataan & $\begin{array}{c}\text { Korelasi } \\
\text { Produk } \\
\text { Moment }\end{array}$ & $\begin{array}{c}\text { r tabel } \\
\mathbf{d f}=\mathbf{5 3}-\mathbf{2} \\
\mathbf{\alpha = 0 , 0 5} \\
\mathbf{2} \text { tailed })\end{array}$ & Keterangan \\
\hline 1 & Q1 & 0,610 & 0,2706 & Valid \\
\hline 2 & Q2 & 0,776 & 0,2706 & Valid \\
\hline 3 & Q3 & 0,440 & 0,2706 & Valid \\
\hline 4 & Q4 & 0,791 & 0,2706 & Valid \\
\hline 5 & Q5 & 0,560 & 0,2706 & Valid \\
\hline 6 & Q6 & 0,460 & 0,2706 & Valid \\
\hline 7 & Q7 & 0,735 & 0,2706 & Valid \\
\hline
\end{tabular}

Sumber : Data diolah penulis

Setelah diuji validitas seluruh pernyataan yang telah diuji memiliki nilai $r$ hitung $\geq \mathrm{r}$ tabel. Dan dapat diperoleh $\mathrm{r}$ tabel $(\mathrm{n}-2)=53$ responden untuk taraf kesalahan 5\% yaitu sebesar 0,270. Berdasarkan hasil tersebut dapat dikatakan bahwa seluruh butir pernyataan tersebut adalah valid sehingga data tersebut telah memenuhi syarat dan penelitian ini dapat dilanjutkan.

b. Hasil Uji Validitas Variabel Pelaksanaan Pemuatan Muatan Berat (X2)

Tabel 3 Uji Validitas Variabel Pelaksanaan Pemuatan Muatan Berat (X2)

\begin{tabular}{|c|c|c|c|c|}
\hline No & Pernyataan & $\begin{array}{c}\text { Korelasi } \\
\text { Produk } \\
\text { Moment }\end{array}$ & $\begin{array}{c}\mathbf{r} \text { tabel } \\
\mathbf{d f = 5 3}-\mathbf{2} \\
\boldsymbol{\alpha}=\mathbf{0 , 0 5} \\
\mathbf{( 2} \text { tailed })\end{array}$ & Keterangan \\
\hline 1 & Q1 & 0,416 & 0,2706 & Valid \\
\hline 2 & Q2 & 0,765 & 0,2706 & Valid \\
\hline 3 & Q3 & 0,834 & 0,2706 & Valid \\
\hline
\end{tabular}




\begin{tabular}{|c|c|c|c|c|}
\hline 4 & Q4 & 0,721 & 0,2706 & Valid \\
\hline 5 & Q5 & 0,611 & 0,2706 & Valid \\
\hline 6 & Q6 & 0,796 & 0,2706 & Valid \\
\hline 7 & Q7 & 0,718 & 0,2706 & Valid \\
\hline
\end{tabular}

\section{Sumber : Data diolah penulis}

Setelah diuji validitas seluruh pernyataan yang telah diuji memiliki nilai $r$ hitung $\geq \mathrm{r}$ tabel. Dan dapat diperoleh $\mathrm{r}$ tabel $(\mathrm{n}-2)=53$ responden untuk taraf kesalahan 5\% yaitu sebesar 0,270. Berdasarkan hasil tersebut dapat dikatakan bahwa seluruh butir pernyataan tersebut adalah valid sehingga data tersebut telah memenuhi syarat dan penelitian ini dapat dilanjutkan.

c. Hasil Uji Validitas Variabel Efektivitas Waktu Muat

Tabel 4 Uji Validitas Variabel Efektivitas Waktu Muat (Y)

\begin{tabular}{|c|c|c|c|c|}
\hline No & Pernyataan & $\begin{array}{c}\text { Korelasi } \\
\text { Produk } \\
\text { Moment }\end{array}$ & $\begin{array}{c}\text { r tabel } \\
\mathbf{d f}=\mathbf{5 3}-\mathbf{2} \\
\boldsymbol{\alpha}=\mathbf{0 , 0 5} \\
\mathbf{( 2 \text { tailed } )}\end{array}$ & Keterangan \\
\hline 1 & Q1 & 0,669 & 0,2706 & Valid \\
\hline 2 & Q2 & 0,297 & 0,2706 & Valid \\
\hline 3 & Q3 & 0,660 & 0,2706 & Valid \\
\hline 4 & Q4 & 0,615 & 0,2706 & Valid \\
\hline 5 & Q5 & 0,666 & 0,2706 & Valid \\
\hline 6 & Q6 & 0,781 & 0,2706 & Valid \\
\hline 7 & Q7 & 0,317 & 0,2706 & Valid \\
\hline
\end{tabular}

Sumber : data diolah penulis

Setelah diuji validitas seluruh pernyataan yang telah diuji memiliki nilai $r$ hitung $\geq \mathrm{r}$ tabel. Dan dapat diperoleh $\mathrm{r}$ tabel $(\mathrm{n}-2)=53$ responden untuk taraf kesalahan 5\% yaitu sebesar 0,270. Berdasarkan hasil tersebut dapat dikatakan bahwa seluruh butir pernyataan tersebut adalah valid sehingga data tersebut telah memenuhi syarat dan penelitian ini dapat dilanjutkan.

\subsubsection{Hasil Uji Reliabilitas}

Hasil Uji Realiabilitas menunjukkan sbb : 
Tabel 5. Uji Reliabilitas Variabel

\begin{tabular}{|c|c|c|c|c|}
\hline Variabel & $\begin{array}{c}\text { Cronbach's } \\
\text { Alpha }\end{array}$ & $>/<$ & Tetapan & Keterangan \\
\hline $\begin{array}{c}\text { Perencanaan Penyusunan } \\
\text { Muatan (X1) }\end{array}$ & 0,746 & $>$ & 0,600 & Realibel \\
\hline $\begin{array}{c}\text { Pelaksanaan Pemuatan } \\
\text { Muatan Berat (X2) }\end{array}$ & 0,820 & $>$ & 0,600 & Realibel \\
\hline \begin{tabular}{c} 
Efektivitas Waktu Muat (Y) \\
\hline
\end{tabular} & 0,630 & $>$ & 0,600 & Realibel \\
\hline
\end{tabular}

Sumber : Olah data,SPSS versi 20

Berdasarkan uji realibilitas Cronbach's Alpha dari ketiga variabel yang digunakan dalam penelitian ini lebih besar dari 0,600. Dan dapat disimpulkan bahwa seluruh pernyataan dari setiap variabel dalam penelitian ini adalah realibel sehingga data tersebut telah memenuhi syarat dan penelitian ini dapat dilanjutkan.

\subsubsection{Analisis Korelasi}

Untuk melihat hubungan antara variabel independen dengan variabel dependen, maka perlu dilakukan analisis korelasi antar variabel penelitian yang hasilnya dapat dilihat pada tabel di bawah ini.

Tabel 6 Analisis Korelasi antar Variabel Correlations

\begin{tabular}{|c|c|c|c|c|}
\hline & & $\begin{array}{c}\text { Perencanaa } \\
\text { n } \\
\text { Penyusunan } \\
\text { Muatan }\end{array}$ & $\begin{array}{c}\text { Pelaksanaa } \\
\text { n Muat } \\
\text { Muatan } \\
\text { berat }\end{array}$ & $\begin{array}{c}\text { Efektivitas } \\
\text { Waktu } \\
\text { Muat }\end{array}$ \\
\hline \multirow{5}{*}{$\begin{array}{l}\text { Perencanaan } \\
\text { Penyusunan Muatan }\end{array}$} & Pearson & 1 & & $305^{*}$ \\
\hline & Correlation & 1 & .001. & \\
\hline & Sig. (2-tailed) & & .664 & .026 \\
\hline & $\mathrm{N}$ & 53 & 53 & 53 \\
\hline & Pearson & 061 & 1 & $681^{* *}$ \\
\hline \multirow{3}{*}{$\begin{array}{l}\text { Pelaksanaan Muat } \\
\text { Muatan berat }\end{array}$} & Correlation & & & \\
\hline & Sig. (2-tailed) & .664 & & .000 \\
\hline & $\mathrm{N}$ & 53 & 53 & 53 \\
\hline \multirow{4}{*}{$\begin{array}{l}\text { Efektivitas Waktu } \\
\text { Muat }\end{array}$} & Pearson & $305^{*}$ & $681^{* *}$ & 1 \\
\hline & Correlation & & & \\
\hline & Sig. (2-tailed) & .026 & .000 & \\
\hline & $\mathrm{N}$ & 53 & 53 & 53 \\
\hline
\end{tabular}

*. Correlation is significant at the 0.05 level (2-tailed).

**. Correlation is significant at the 0.01 level (2-tailed).

Sumber: Data diolah penulis 
Dari Tabel di atas terlihat bahwa nilai koefisien korelasi antara Perencanaan Penyusunan Muatan (X1) dengan Efektivitas Waktu Muat (Y) sebesar 0,305 yang menunjukkan hubungan yang rendah karena berada pada interval $(0,200-0,399)$. Sedangkan nilai koefisien korelasi antara pelaksanaan pemuatan (X2) dengan efektivitas waktu muat (Y) sebesar 0,681 yang menunjukkan hubungan yang kuat karena berada pada interval $(0,600-0,799)$. Berdasarkan kedua koefisien korelasi di atas ternyata kedua variabel mempunyai hubungan yang cukup signifikan pada taraf nyata (alpha) jauh di bawah 5\% $(0,05)$ yaitu perencanaan penyusunan muatan $(0,026)$ dan pelaksanaan pemuatan $(0,000)$.

\subsection{Analisis Data dengan Statistik Inferensial dan pengujian Hipotesis Statistik}

\subsubsection{Analisis Regresi Linier Berganda}

Analisis regresi linier berganda digunakan untuk mengetahui besarnya pengaruh variabel perencanaan penyusunan muatan (X1) dan pelaksanaan pemuatan muatan berat (X2), secara parsial maupun secara bersama-sama terhadap efektivitas waktu muat (Y). Model persamaan regresi yang dapat dituliskan dari hasil perhitungan dalam bentuk persamaan regresi adalah sebagai berikut:

$\mathbf{Y}=\mathbf{6 , 3 7 6}+\mathbf{0 , 2 3 2} \mathrm{X1}+\mathbf{0 , 4 9 8 X 2}$. Nilai konstanta $\mathbf{a}=\mathbf{6 , 3 7 6}$ memberikan arti bahwa jika variabel bebas diabaikan atau dengan kata lain jika tidak ada variasi pada perencanaan penyusunan muatan dan pelaksanaan pemuatan, maka efektivitas waktu muat akan bernilai 6,376 . Nilai koefisien $b 1=0,232$ hal ini berarti bahwa setiap perubahan satu satuan pada perencanaan penyusunan muatan dengan asumsi variabel pelaksanaan pemuatan konstan, maka efektivitas waktu muat akan mengalami peningkatan sebesar 0,232 dan bergerak ke arah yang sama. Nilai koefisien $b 2=0,498$ hal ini berarti bahwa setiap perubahan satu satuan pada pelaksanaan pemuatan dengan asumsi variabel perencanaan penyusunan muatan konstan, maka efektivitas waktu muat akan mengalami peningkatan sebesar 0,505 dan bergerak ke arah yang sama.

\subsubsection{Uji Hipotesis}

Uji t digunakan untuk mengetahui pengaruh secara parsial variabel independen (perencanaan penyusunan muatan dan pelaksanaan pemuatan) terhadap variabel dependen (efektivitas waktu muat).

a) Pengaruh Perencanaan Penyusunan Muatan (X1) terhadap Efektivitas Waktu Muat (Y)

Dari hasil uji $\mathrm{t}$ untuk variabel $\mathrm{X} 1$ (perencanaan penyusunan muatan) diperoleh nilai $\mathrm{t}$ hitung $=$ $(2,736)$ dengan nilai signifikansi $=0,009$. Dengan menggunakan batas signifikansi 0,05 , didapat $\mathrm{t}$ tabel $(n=53)$ sebesar 2,009. Hal ini berarti $t$ hitung $>t$ tabel, yang berarti Ho ditolak dan Ha diterima. Dengan demikian, maka hipotesis pertama telah terbukti. Berdasarkan hasil tersebut dapat disimpulkan bahwa terdapat pengaruh positif signifikan antara perencanaan penyusunan 
muatan terhadap efektivitas waktu muat.

b) Pengaruh Pelaksanaan Pemuatan (X2) terhadap Efektivitas waktu muat (Y)

Dari hasil uji t untuk variabel X2 (pelaksanaan pemuatan) diperoleh nilai t hitung $=6,877$ dengan nilai signifikansi $=0,000$. Dengan menggunakan batas signifikansi 0,05 , didapat $\mathrm{t}$ tabel $(\mathrm{n}=53)$ sebesar 2,009. Hal ini berarti t hitung > t tabel, yang berarti Ho diterima dan Ha ditolak. Dengan demikian, maka hipotesis pertama telah terbukti. Berdasarkan hasil tersebut dapat disimpulkan bahwa terdapat pengaruh positif signifikan antara pelaksanaan pemuatan terhadap efektivitas waktu muat.

\subsubsection{Uji F Pengaruh Perencanaan Penyusunan Muatan dan Pelaksanaan Pemuatan terhadap Efektivitas}

\section{Waktu Muat}

Dari hasil perhitungan diketahui bahwa secara simultan (bersama-sama) variabel independen (perencanaan penyusunan muatan dan pelaksanaan pemuatan) mempunyai nilai $\mathrm{F}$ hitung $=28,642>\mathrm{F}$ tabel $=3,18$, demikian juga nilai signifikansi yang diperoleh sebesar $0,000<0,05$. Sehingga dapat dikatakan bahwa perencanaan penyusunan muatan dan pelaksanaan pemuatan secara simultan berpengaruh signifikan terhadap efektivitas waktu muat. Berdasarkan hasil tersebut, maka hipotesis ketiga telah terbukti.

\subsubsection{Koefisien Determinasi}

Besarnya kontribusi perencanaan penyusunan muatan dan pelaksanaan pemuatan terhadap efektivitas waktu muat adalah sebesar $53,4 \%$ sedangkan sisanya 46,6\% merupakan pengaruh faktor lain.

\subsubsection{Analisis Korelasi Ganda}

Setelah dilakukan pengujian menggunakan SPSS 20.00, maka didapatkan hasil output sebagai berikut :

a) Hasil Pengujian Hipotesis

- Berdasarkan hasil analisis data diperoleh bahwa variabel perencanaan penyusunan muatan berpengaruh terhadap variabel efektivitas waktu muat. Berdasarkan hasil perhitungan koefisien korelasi $\mathrm{r}^{2}=0.093$ yang menunjukan adanya pengaruh sangat rendah dengan nilai thitung $=$ 2,736 dan ttabel $=2,009$. Fakta ini mengungkapkan bahwa thitung $>$ ttabel berarti $\mathrm{H} 0$ ditolak dan H1 diterima. Dari hasil diatas menunjukkan bahwa variabel perencanaan penyusunan muatan memberikan pengaruh yang signifikan terhadap efektivitas waktu muat, maka hipotesis pertama telah terbukti.

- Berdasarkan hasil analisis data diperoleh bahwa variabel pelaksanaan pemuatan berpengaruh 
- terhadap variabel efektivitas waktu muat. Berdasarkan hasil perhitungan koefisien korelasi $\mathrm{r}^{2}$ $=0.464$ yang menunjukan adanya pengaruh sedang dengan nilai thitung $=6,877$ dan tabel $=$ 2,009. Fakta ini mengungkapkan bahwa thitung > ttabel berarti H0 ditolak dan H1 diterima. Dari hasil diatas menunjukkan bahwa variabel pelaksanaan pemuatan memberikan pengaruh yang signifikan terhadap efektivitas waktu muat, maka hipotesis kedua telah terbukti.

- Berdasarkan hasil uji simultan (uji F) untuk menguji variabel secara keseluruhan dimana variabel X1 dan X2 memberikan pengaruh terhadap variabel Y secara simultan, didapatkan hasil analisis Fhitung sebesar 28,642 dan untuk nilai Ftabel sebesar 3,18 . Maka nilai Fhitung > Ftabel itu membuktikan bahwa Ho ditolak dan Ha diterima. Kemudian, Berdasarkan dari hasil analisis korelasi berganda di dapat R yaitu sebesar 0,731 . Jadi, dari uji simultan (uji F) dan hasil analisis korelasi berganda yaitu R dapat disimpulkan variabel X1 (pengaruh perencanaan penyusunan muatan) dan X2 (pelaksanaan pemuatan) secara Bersama- sama berpengaruh signifikan terhadap variabel Y (efektivitas waktu muat) dan memiliki tingkat hubungan yang kuat, maka hipotesis ketiga telah terbukti.

\subsection{Deskripsi atas Hasil-hasil Analisis}

Secara umum hasil analisis deskriptif menunjukkan bahwa kondisi penilaian responden terhadap perencanaan penyusunan muatan dan pelaksanaan pemuatan serta efektivitas waktu muat secara umum cukup baik. Hal ini dapat ditunjukkan dari banyaknya tanggapan kesetujuan yang tinggi dari responden terhadap kondisi dari masing-masing variabel tersebut. Dari hasil analisis regresi berganda diketahui bahwa terdapat pengaruh positif signifikan dari variabel perencanaan penyusunan muatan (X1) dan pelaksanaan pemuatan (X2) terhadap variabel efektivitas waktu muat (Y) secara simultan. Sedangkan kontribusi dari variabel perencanaan penyusunan muatan dan pelaksanaan pemuatan adalah sebesar 53,4\% yang berarti cukup signifikan dalam meningkatkan efektivitas waktu muat sedangkan sisanya 46,6\% merupakan pengaruh faktor lain. Berdasarkan uji hipótesis secara parsial diketahui bahwa terdapat pengaruh antara variabel perencanaan penyusunan muatan (X1) terhadap efektivitas waktu muat dengan nilai t hitung sebesar 2,736>t tabel $(2,009)$ dan dengan nilai signifikansi sebesar 0,009 $<0,05(5 \%)$ yang menunjukkan adanya pengaruh yang signifikan. Hal ini berarti terdapat pengaruh positif signifikan antara variabel perencanaan penyusunan muatan (X1) terhadap efektivitas waktu muat $(\mathrm{Y})$ dan hipótesis yang menyatakan "terdapat pengaruh positif signifikan variabel perencanaan penyusunan muatan terhadap efektivitas waktu muat" telah terbukti. 
berdasarkan uji hipótesis secara parsial diketahui bahwa terdapat pengaruh antara variable pelaksanaan pemuatan (X2) terhadap efektivitas waktu muat dengan nilai $\mathrm{t}$ hitung sebesar 6,877 >t tabel $(2,009)$ dengan nilai signifikansi sebesar $0,000<0,05(5 \%)$ yang menunjukkan adanya pengaruh signifikan antara variabel pelaksanaan pemuatan terhadap efektivitas waktu muat. Sehingga dapat disimpulkan bahwa hipotesis yang menyatakan "terdapat pengaruh positif signifikan variabel pelaksanaan pemuatan terhadap efektivitas waktu muat" telah terbukti. Hasil analisis di atas sudah cukup memberikan bukti terhadap hipotesis yang telah dirumuskan dalam penelitian ini. Artinya dalam konteks model dalam penelitian yang telah dirancang dalam bentuk linier sudah cukup memberikan hasil prediksi yang nyata terhadap parameter dalam model regresi tersebut. Dengan demikian kalau dilihat dari sisi ada tidaknya pengaruh variabel-variabel independen, maka model ini sudah menjadi bukti yang cukup dalam menjawab permasalahan penelitian.

\section{KESIMPULAN}

Dari hasil analisa yang dilakukan penulis maka dapat disimpulkan sebagai berikut: bahwa Berdasarkan hasil uji parsial (uji t) untuk menguji pengaruh antara variabel X1 dengan variabel Y, menunjukkan bahwa variabel perencanaan penyusunan muatan memberikan pengaruh yang signifikan terhadap efektivitas waktu muat, Dengan nilai koefisien korelasi sebesar 0.305 atau 30.5\%. sedangkan Berdasarkan hasil uji parsial (uji t) untuk menguji pengaruh antara variabel X2 dengan variabel Y, menunjukkan bahwa variabel pelaksanaan pemuatan memberikan pengaruh yang signifikan terhadap variabel efektivitas waktu muat, Dengan nilai koefisien korelasi 0,681 atau 68.1\%.Dan Berdasarkan hasil uji simultan (uji F) untuk menguji variabel secara keseluruhan dimana variabel X1 dan X2 memberikan pengaruh terhadap variabel Y secara simultan, dari hasil uji F didapat hasil Fhitung sebesar 28,642 dan untuk nilai Ftabel sebesar 3,17. Maka nilai Fhitung > Ftabel itu membuktikan bahwa Ho ditolak dan Ha diterima. Kemudian, Berdasarkan dari hasil analisis korelasi berganda di dapat R yaitu sebesar 0,731 . Jadi, dari uji simultan (uji F) dan hasil analisis korelasi berganda yaitu R dapat disimpulkan variabel X1 (Perencanaan Penyusunan Muatan) dan X2 (Pelaksanaan Pemuatan Muatan Berat) secara Bersama- sama berpengaruh signifikan terhadap variabel Y (Efektivitas Waktu Muat) dan memiliki tingkat hubungan yang kuat. dari perhitungan koefisien determinasi maka dapat hasil besarnya nilai kontribusi dari pengaruh X1 dan X2 terhadap Y yaitu : Koefisien Determinasi sebesar $53,4 \%$. 


\section{DAFTAR PUSTAKA}

[1] Agung, Pratama, W. P. (2014). Pelaksanaan Memuat Batu bara di MV. Andhika Sharmila dengan Menggunakan Floating Crane. Politeknik Ilmu Pelayaran Semarang.

[2] Avriel, Mordecai, Michael Penn, N. S. and S. W. (1998). stowage planning for container ships to reduce the number of shifts. Annals of Operation Research 76, 76, 55-71. https://doi.org/10.1023/A

[3] Bliault, C. and N. of E. Pe. A. (2007). Cargo Stowage and Securing. Safe Ship/Safe Cargo Conference, 2nd (second edi). Newcastle: North of England PEtl Association. Retrieved from http://trid.trb.org/view.aspx?id=397688

[4] Kemenhub. PERATURAN MENTER! PERHUBUNGAN REPUBLIK INDONESIA NOMOR PM 74 TAHUN 2016 TENT ANG PERUBAHAN ATAS PERATURAN MENTER! PERHUBUNGAN NOMOR PM 93 TAHUN 2013 TENTANG PENYELENGGARAAN DAN PENGUSAHAAN ANGKUTAN LAUT, Pub. L. No. BERITA NEGARA REPUBLIK INDONESIA TAHUN 2016 NOMOR 966 (2016). Indonesia: Kementrian Perhubungan RI.

[5] Kosasih, E. \& C. H. S. (2000). Manajemen Perusahaan Pelayaran. Jakarta: PT. Erlangga.

[6] Mahmudi. (2005). Manajemen Kinerja Sektor Publik. Yogyakarta: UPP AMP YKPN. Martopo, C. A. \& S. (1999). Kapal dan Muatannya, Semarang. semarang: Politeknik Negeri Semarang.

[7] Martopo, C. A. \& S. (2004). Penanganan Muatan. semarang: Politeknik Negeri Pelayaran.

[8] Mirade, Architania, Rifani., Rinitami, Njatrijani., \& Hendro, S. (206AD). Pelaksanaan Bongkar Muat Barang pada PT. Pelabuhan Indonesia III Cabang Tanjung Intan Cilacap. Jurnal Undip, $5(2)$.

[9] Mudiyanto. (2018). Modul Digital Pelayaran kapal Niaga KB-01 : Penanganan DanPengaturan Muatan. Jakarta.

[10] Nutfah, Indah, S. (2007). Analisa Kinerja dan Efektivitas Bongkar Muat PadaTerminal Petikemas (TPK) Koja. Universitas Gunadarma.

[11] Øvstebø, B. O., Hvattum, L. M., \& Fagerholt, K. (2011). Optimization of stowage plans for RoRo ships. Computers and Operations Research, 38(10), 1425-1434. https://doi.org/10.1016/j.cor.2011.01.004

[12] Prasetyo, L., \& \& Benny, Agus, S. (2011). (2011). Peranan Fasilitas Pelabuhan Dalam Menunjang Kegiatan Bongkar Muat di Divisi Terminal Jamrud PT. Pelabuhan Indonesia III 
(Persero) Cabang Tanjung Perak Surabaya. Jurnal Aplikasi Pelayaran Dan Kepelabuhanan, Vol 2, 2(1), 62-64.

[13] Setiono, M. A. Y. B. A. (2013). Efektifitas Bongkar Muat Petikemas Terhadap Kelancaran Arus Barang di PT Nilam Port Terminal Indonesia (NPTI ) Cabang Tanjung Perak Surabaya (Effectiveness of Unloading Containers to The Smooth Flow of Goods in PT Nilam Port Terminal Indonesia (NPT). Jurnal Aplikasi Pelayaran Dan Kepelabuhanan, 4, 47.

[14] Zumar, V. V. dan H. (2018). Desain Multipurpose Landing Craft Tank ( LCT ) Menggunakan Metode Optimisasi Global dan Lokal. Jurnal Teknik ITS, 7(1), G99- G104. 